\title{
ESTIMASI MODEL LOGIT UNTUK MELIHAT EFEK MODEL PEMBELAJARAN YANG BERBEDA TERHADAP NILAI AKHIR MAHASISWA PADA MATA KULIAH KALKULUS
}

\author{
Desty Rakhmawati ${ }^{1}$, Rokhanah Puji Lestari ${ }^{2}$ \\ ${ }^{1,2}$ Fakultas Ilmu Komputer, Universitas Amikom Purwokerto \\ email : desty@amikompurwokerto.ac.id
}

RIWAYAT ARTIKEL

Diterima(08-11-2019)

Revisi (21-11-2019)

Diterbitkan(30-12-2019)

\section{ABSTRAK}

Kalkulus adalah mata kuliah yang wajib diambil oleh mahasiswa Teknik Informatika Universitas Amikom Purwokerto. Permasalahan yang dialami oleh mahasiswa terkait dengan mata kuliah kalkulus adalah karena mahasiswa selalu beranggapan bahwa kalkulus atau matematika adalah mata kuliah yang sulit. Dengan adanya anggapan seperti itu, akan berdampak terhadap nilai akhir mahasiswa yang tidak tuntas. Oleh karena itu dengan adanya masalah tersebut, penelitian ini bertujuan untuk menggunakan model pembelajaran yang dapat mengubah anggapan mahasiswa, yaitu dengan menerapkan model pembelajaran group resume dan juga model pembelajaran lain yang berbeda. Dengan menerapkan model pembelajaran yang berbeda ini, akan dilihat apakah ada efek nya terhadap hasil akhir mahasiswa untuk mendapatkan nilai A. Untuk melihat pengaruh model pembelajaran yang berbeda terhadap nilai akhir mahasiswa, dilakukan dengan menggunakan analisis regresi logistik model logit. Estimasi pembentukan model logit ini, dilakukan dengan menggunakan software EViews 9. Dan setelah dimodelkan diperoleh hasil bahwa jika menggunakan model pembelajaran group resume, maka akan meningkatkan nilai odd ratio untuk mendapatkan nilai A sebesar 7,159090874 kali. Dengan kata lain, adanya pengaruh penggunaan model pembelajaran yang berbeda terhadap nilai akhir mahasiswa.

Kata kunci: Kalkulus, Model Logit, Model Pembelajaran 


\begin{abstract}
Calculus is a subject that must be taken by students of Informatics Engineering at the University of Amikom Purwokerto. The problems experienced by students related to calculus courses are because students always assume that calculus or mathematics is a difficult subject. With such an assumption, it will impact on the students' final grades which are not complete. Therefore, with this problem, this research aims to use a learning model that can change students' perceptions, namely by applying the group resume learning model and other different learning models. By applying this different learning model, it will be seen whether there is an effect on the student's final result to get an A. To see the effect of different learning models on the student's final grade, it is performed using a logistic regression analysis model. logit Estimation of the formation of this logit model is done using EViews 9. And after modeling it results that if using the group resume learning model, it will increase the odds ratio to get an A value of 7.159090874 times. In other words, there is an influence of the use of different learning models on the student's final grade
\end{abstract}

Key words: Calculus, Logit Model, Leraning Model

\title{
1. Pendahuluan
}

Kalkulus adalah mata kuliah yang berkaitan dengan matematika. Kalkulus merupakan mata kuliah wajib yang diambil oleh mahasiswa semester pertama dan kedua di prodi Teknik Informatika. Salah satu permasalahan yang ada berdasarkan hasil dari observasi dan juga wawancara terhadap mahasiswa beserta dosen pengampu mata kuliah kalkulus program studi Teknik Informatika di Universitas Amikom Purwokerto, menjelaskan bahwa mahasiswa Teknik Informatika yang sudah mengambil mata kuliah kalkulus mengalami kesulitan dalam memahami mata kuliah kalkulus. Hal ini akan berakibat pada ketidaklulusnya pada mata kuliah kalkulus. Berdasarkan pengalaman peneliti dalam mengampu mata kuliah kalkulus mahasiswa Teknik Informatika di Universitas Amikom Purwokerto, beberapa faktor yang dapat menyebabkan ketidaklulusnya mata kuliah kalkulus diantaranya adalah karena mahasiswa selalu beranggapan bahwa kalkulus atau matematika adalah mata kuliah yang sulit. Dengan selalu beranggapan seperti itu, sehingga mahasiswa kurang antusias dalam mengikuti pembelajaran dan berakibat pada hasil akhir nilai kalkulus yang tidak tuntas. Kesulitan belajar kalkulus 1 mahasiswa Teknik Informatika menurut (Mutakin, 2013) diantaranya adalah mahasiswa beranggapan bahwa Kalkulus 1 tidak ada kaitannya dengan Prodi Teknik Informatika dan mahasiswa kurang menyukai kalkulus 1 . Untuk menangani permasalahan tersebut, peneliti mencoba menerapkan model pembelajaran yang dapat mengubah anggapan-anggapan mahasiswa tersebut. Dan menurut (Wahyuni, 2017), menjelaskan salah satu hambatan atau kesulitan belajar yang dapat dialami oleh peserta didik pada saat proses pembelajaran adalah hambatan didaktis atau hambatan akibat pengajaran pendidik yaitu hambatan dalam pembelajaran yang berasal dari pemberian konsep yang salah atupun pengajaran konsep yang tidak sesuai dengan kesiapan anak.

Terkait dengan hambatan didaktis, dan agar pemberian konsep pengajaran lebih sesuai, 
serta menjadikan kalkulus adalah mata kuliah yang menyenangkan (tidak sulit), oleh karena itu peneliti melakukan penelitian dengan menerapkan model pembelajaran yang dapat mengubah anggapan mahasiswa tersebut. Model pembelajaran yang digunakan adalah model pembelajaran kooperatif. Hal ini dikarenakan menurut (Sutiman, Antuni Wiyarsi, 2014), bahwa model pembelajaran kooperatif telah dikembangkan secara intensif melalui berbagai penelitian, dan berpijak pada beberapa pendekatan yang diasumsikan mampu meningkatkan hasil belajar mahasiswa, serta berpengaruh dalam peningkatan kemampuan menyelesaikan masalah yang ada pada pembelajaran. Model pembelajaran kooperatif menurut (Isjoni, 2009), terdapat beberapa model yang dapat diterapkan, salah satunya adalah group resume. Model pembelajaran group resume ini, adalah model dimana, peserta didik dibentuk menjadi beberapa kelompok, kemudian didalam kelompok tersebut membuat inti atau pokok dari materi yang dibahas yaitu inti materi yang akan disampaikan kepada kelompok lain. Pada model pembelajaran kooperatif group resume, dapat menjadikan interaksi antar peserta didik lebih baik, dengan memberi penekanan bahwa mereka adalah kelompok yang bagus, dalam bakat dan kemampuannya di kelas. Dengan adanya kelompok pembelajaran ini, akan diharapkan asumsi bahwa kalkulus itu sulit dapat dihilangkan dan nantinya akan berdampak terhadap nilai akhir (kelulusan) mata kuliah kalkulus ini. Dengan menerapkan model pembelajaran group resume, ini akan diharapkan dapat meningkatkan hasil belajar peserta didik, Seperti hal nya dengan penelitian yang sudah dilakukan oleh (Anas dan Murti,2017). Hasil penelitiannya menjelaskan bahwa model pembelajaran kooperatif model group resume, dapat meningkatkan hasil belajar peserta didik.

Efek penggunaan model pembelajaran kooperatif group resume terhadap nilai akhir mata kuliah kalkulus dapat dianalisis menggunakan analisis regresi logistik. Regresi logistik merupakan salah satu model statistika yang dapat digunakan untuk menganalisis pola hubungan antara sekumpulan variabel independent, dengan variabel dependent yang bertipe kategorik atau kualitatif (Rosadi, 2012). Berdasarkan variabel dependent, regresi logistik menurut (Darnah, 2011), dibagi menjadi tiga, yaitu regresi logistik biner, logistik ordinal dan logistik nominal. Karena pada penelitian ini bertujuan untuk melihat pengaruh penggunaan model pembelajaran yang berbeda (model pembelajaran group resume dan model pembelajaran selain group resume) terhadap nilai mata kuliah kalkulus. Oleh karena itu, regresi logistik yang akan digunakan adalah regresi logistik ordinal. Regresi logistik ordinal digunakan untuk menganalisis variabel dependent yang mempunyai skala ordinal yang terdiri atas dua kategori atau lebih. Model regresi logistik ini dapat dibagi menjadi dua model yaitu model logit dan probit (Rosadi, 2011). Pada penelitian ini, dimana model pembelajaran sebagai variabel dependent dan bersifat biner, sehingga model regresi logistik ordinal yang digunakan adalah model logit biner. Dan menurut (Muinah Kusnul Kotimah dan Sri Pingit Wulandari, 2014) regresi logistik biner dapat digunakan untuk mencari hubungan antara variabel dependent(y) yang bersifat biner dengan variabel independent $(x)$.

Persamaan regresi logistik dan bentuk dari model logit menurut(Dewi, S. R, dkk, 2018), masing- masing dapat dilihat pada persamaan (1) dan (2) dibawah ini 


$$
\begin{aligned}
& P(Y=j \mid x)=\pi(x)=\frac{e^{\beta_{j 0}+\beta_{j 1} x_{1}+\cdots+\beta_{j p} x_{p}}}{1+e^{\beta_{j 0}+\beta_{j 1} x_{1}+\cdots+\beta_{j p} x_{p}}} \\
& g(x)=\beta_{j 0}+\beta_{j 1} x_{1}+\cdots+\beta_{j p} x_{p}
\end{aligned}
$$

Dimana :

$\beta$ :Koefisien regresi atau parameter model

$x_{s}$ :Nilai dari variabel dependentke- $s, s=1,2,3, \ldots, p$

$\pi(x)$ : Persamaan regresi logistik untuk variabel respon kategori ke-j

$P(Y=j \mid x)$ : Peluang bersyarat dari variabel respon kategori ke-jpada variabel $x$, dan $j=0,1,2, \ldots, n$.

Persamaan regresi logistik dan bentuk dari model logitpada persamaan (1) dan (2) diatas akan digunakan untuk melihat pengaruh dari perlakuan model pembelajaran yang berbeda terhadap nilai akhir mahasiswa.

\section{Metode Penelitian}

Penelitian yang dilakukan merupakan jenis penelitian kuantitatif. Data yang digunakan adalah data terkait dengan nilai mata kuliah kalkulus 2 mahasiswa Teknik Informatika Universitas Amikom Purwokerto dengan menggunakan model pembelajaran yang berbeda. Waktu penelitian dilaksanakan pada Tahun pembelajaran 2018/2019 semester genap. Target/ sasaran penelitian adalah mahasiswa yang mengambil mata kuliah kalkulus 2 yang diperlakukan dengan menggunakan model pembelajaran group resume, model pembelajaran secara langsung dan model pembelajaran student team achievement division.Sehingga sampel yang digunakan sebanyak 67 yang terdiri dari 18 mahasiswa yang diperlakukan menggunakan model pembelajaran group resume dan 23 mahasiswa diperlakukan menggunakan model pembelajaran secara langsung dan 26 mahasiswa diperlakukan menggunakan model pembelajaran student team achievement division. Sebelum dilakukan analisis data, semua mahasiswa yang menjadi sampel diberikan pretest untuk mendapatkan nilai awal serta untuk melihat kemampuan awal sebelum dilaksanakan pembelajaran. Dengan menggunakan nilai awal dan dengan perlakuan menggunakan model pembelajaran yang berbeda, akan dibentuk model logistik logit untuk melihat pengaruhnya terhadap nilai akhir mahasiswa yang menjadi sampel tersebut.

\subsection{Prosedur Penelitian}

Penelitian ini dilaksanakan dengan menggunakan prosedur seperti dibawah ini

a. Penentuan sampel penelitian yang diperlakukan dengan menggunakan model pembelajaran yang berbeda. Dimana untuk satu kelas menerapkan model pembelajaran group resume dan dua kelas lainnya tidak menggunakan model pembelajaran group resume, akan tetapi menggunakan model pembelajaran secara langsung dan model pembelajaran student team achievement division.

b. Pemberian pretest sebelum diperlakukan menggunakan model pembelajaran yang berbeda. 
c. Peroses pembelajaran dengan menerapkan model pembelajaran yang berbeda.

d. Pemberian ujian setelah diperlakukan dengan menggunakan model pembelajaran yang berbeda.

e. Analisis data dengan cara mengestimasi model logistik logit, untuk melihat efek penggunaan model pembelajaran yang berbeda terhadap nilai akhir mahasiswa.

\subsection{Teknik Analisis Data}

Proses dalam analisis data, untuk memodelkan masalah efek model pembelajaran yang berbeda terhadap nilai akhir mahasiswa, dengan menggunakan variabel- variabel berikut

a. $x_{1}=$ Nilai awal (Nilai pretest)

b. $x_{2}=$ Model pembelajaran yang berbeda. Nilai 1 untuk model pembelajaran group resume dan 0 untuk model pembelajaran selain group resume.

c. $y=$ Nilai akhir setelah diperlakukan menggunakan model pembelajaran yang berbeda. Jika bernilai 1, maka nilai akhir A. dan jika nilai akhir selain A, maka bernilai 0 .

Setelah dibentuk variabel- variabel diatas, selanjutnya dilakukan estimasi untuk membentuk model regresi logistik dan bentuk logit seperti pada persamaan (1) dan (2) diatas. Kedua model tersebut diperoleh dengan menganalisis data dengan menggunakan software EViews 9. Selanjutnya model- model tersebut, yang terbentuk menggunakan software EViews 9, akan digunakan untuk melihat efek dari penggunaan model pembelajaran dan nilai awal, terhadap nilai akhir mahasiswa.

\section{Hasil dan Pembahasan}

\subsection{Data}

Data yang digunakan untuk mengestimasi model logistik bentuk logit adalah data nilai pretest mahasiswa yang mengambil mata kuliah kalkulus 2 program studi Teknik Informatika Universitas Amikom Purwokerto semester genap Tahun Ajaran 2018/2019. Setelah dilakukan pretest, selanjutnya adalah proses perkuliahan dengan memperlakukan menggunakan model pembelajaran group resume dan selain model pembelajaran group resume. Dan diperoleh hasil pembelajaran menggunakan masing- masing model pembelajaran. Data tersebut dapat dilihat pada Tabel 1. di bawah ini 
Tabel 1. Data Penelitian

\begin{tabular}{|c|c|c|c|c|c|c|c|}
\hline Responden & Nilai Akhir & Nilai Awal & Model & Responden & Nilai Akhir & Nilai Awal & Model \\
\hline $\mathbf{i}$ & $y$ & $x_{1}$ & $x_{2}$ & $\mathrm{i}$ & $y$ & $x_{1}$ & $x_{2}$ \\
\hline 1 & 0 & 94 & 0 & 35 & 1 & 98 & 1 \\
\hline 2 & 0 & 62 & 0 & 36 & 1 & 56 & 1 \\
\hline 3 & 0 & 76 & 0 & 37 & 0 & 49 & 1 \\
\hline 4 & 0 & 94 & 0 & 38 & 0 & 63 & 1 \\
\hline 5 & 0 & 55 & 0 & 39 & 1 & 41 & 1 \\
\hline 6 & 0 & 58 & 0 & 40 & 1 & 80 & 1 \\
\hline 7 & 0 & 80 & 0 & 41 & 0 & 38 & 1 \\
\hline 8 & 0 & 94 & 0 & 42 & 0 & 64 & 0 \\
\hline 9 & 0 & 61 & 0 & 43 & 0 & 66 & 0 \\
\hline 10 & 0 & 90 & 0 & 44 & 0 & 68 & 0 \\
\hline 11 & 0 & 47 & 0 & 45 & 0 & 69 & 0 \\
\hline 12 & 0 & 53 & 0 & 46 & 0 & 34 & 0 \\
\hline 13 & 0 & 46 & 0 & 47 & 0 & 53 & 0 \\
\hline 14 & 0 & 73 & 0 & 48 & 0 & 98 & 0 \\
\hline 15 & 0 & 77 & 0 & 49 & 1 & 63 & 0 \\
\hline 16 & 0 & 36 & 0 & 50 & 0 & 73 & 0 \\
\hline 17 & 0 & 68 & 0 & 51 & 0 & 78 & 0 \\
\hline 18 & 0 & 82 & 0 & 52 & 0 & 98 & 0 \\
\hline 19 & 0 & 58 & 0 & 53 & 0 & 75 & 0 \\
\hline 20 & 0 & 94 & 0 & 54 & 0 & 77 & 0 \\
\hline 21 & 0 & 70 & 0 & 55 & 0 & 70 & 0 \\
\hline 22 & 1 & 83 & 0 & 56 & 1 & 86 & 0 \\
\hline 23 & 1 & 85 & 0 & 57 & 0 & 43 & 0 \\
\hline 24 & 1 & 65 & 1 & 58 & 0 & 80 & 0 \\
\hline 25 & 0 & 75 & 1 & 59 & 0 & 68 & 0 \\
\hline 26 & 1 & 72 & 1 & 60 & 0 & 71 & 0 \\
\hline 27 & 0 & 48 & 1 & 61 & 0 & 68 & 0 \\
\hline 28 & 0 & 57 & 1 & 62 & 0 & 71 & 0 \\
\hline 29 & 0 & 90 & 1 & 63 & 0 & 96 & 0 \\
\hline 30 & 0 & 61 & 1 & 64 & 0 & 42 & 0 \\
\hline 31 & 0 & 54 & 1 & 65 & 0 & 75 & 0 \\
\hline 32 & 0 & 71 & 1 & 66 & 0 & 74 & 0 \\
\hline 33 & 0 & 74 & 1 & 67 & 0 & 40 & 0 \\
\hline 34 & 1 & 79 & 1 & & & & \\
\hline
\end{tabular}


Tabel 1. di atas, menjelaskan bahwa $x_{1}$ adalah nilai awal yang diperoleh sebelum dilakukan perlakuan menggunakan model pembelajaran. Kemudian $x_{2}$ adalah model pembelajaran yang diterapkan kepada responden ke $i$. Jika $x_{2}=1$, artinya responden diperlakukan menggunakan model pembelajaran group resume, sedangkan jika $x_{2}=0$, maka artinya responden tidak diperlakukan menggunakan model pembelajaran group resume. Variabel yadalah variabel yang mewakili nilai akhir setelah diperlakukan menggunakan model pembelajaran yang berbeda. Jika $y=1$, maka responden memperoleh nilai A, sedangkan apabila $y=0$, maka artinya responden mendapatkan nilai selain A. Setelah data diatas, didapatkan selanjutnya adalah mengestimasi model logistik logit untuk melihat efek penggunaan model pembelajaran terhadap nilai akhir responden.

\subsection{Model Logit}

Model logit dari data pada Tabel 1. di atas diestimasi dengan menggunakan software EViews 9. Pada analisis menggunakan software EViews 9, jika variabel $x_{1}=$ A dan variabel $x_{2}=\mathrm{M}$, serta dengan menggunakan tingkat signifikansi sebesar 5\%, maka Output dari estimasi menggunakan data pada Tabel 1. dapat dilihat pada Tabel 2. di bawah ini.

Tabel 2. Hasil Estimasi Model

\begin{tabular}{crrrr}
\hline \hline Variable & Coefficient & Std. Error & z-Statistic & Prob. \\
\hline \hline C & -5.194636 & 1.970615 & -2.636049 & 0.0084 \\
A & 0.037402 & 0.024379 & 1.534202 & 0.1250 \\
M & 2.274585 & 0.777985 & 2.923686 & 0.0035 \\
\hline \hline
\end{tabular}

Tabel 2. menjelaskan bahwa untuk variabel $x_{1}$ sebagai nilai awal (A), diperoleh nilai prob. ( $p$-value) sebesar 0,1250. Jika $p$-value lebih besar dari tingkat signifikansi (5\%), artinya variabelnilai awal tidak berpengaruh terhadap nilai akhir $(y)$ responden. Karena variabel A tidak berpengaruh terhadap model sehingga, diestimasi ulang dengan mengeluarkan variabel A, dan diperoleh output yang dapat dilihat pada Tabel 3. sebagai berikut

Tabel 3. Hasil Estimasi Model Logit

\begin{tabular}{crrrr}
\hline \hline Variable & Coefficient & Std. Error & z-Statistic & Prob. \\
\hline \hline C & -2.420368 & 0.521749 & -4.638949 & 0.0000 \\
M & 1.968383 & 0.711329 & 2.767192 & 0.0057 \\
\hline \hline
\end{tabular}

Tabel 3. di atas, memperlihatkan, hasil estimasi dari model logit. Untuk nilai $p$-value dari variabel model pembelajaran $\left(x_{2}\right)$ atau $\mathrm{M}$ nilai nya lebih kecil dari tingkat signifikansi, ini artinya bahwa variabel model pembelajaran berpengaruh signifikansi terhadap nilai akhir dari responden. Dengan kata lain hasil estimasi diatas dapat membentuk model logit yang tepat. Dan model yang terbentuk dengan mengacu pada persamaan (1) dan (2) diatas adalah seperti pada persamaan (3) dan (4) di bawah ini.

$P(Y=j \mid x)=\pi(x)=\frac{e^{-2.420368+1.968383 x_{2}}}{1+e^{-2.420368+1.968383 x_{2}}}$

$g(x)=-2.420368+1.968383 x_{2}$

Persamaan (3) di atas, merupakan model regresi logistik, dan untuk model logit dapat dilihat pada persamaan (4) di atas. Untuk melihat Goodness of fit dari model logit 
terbaik dari variabel nilai akhir diatas, dapat dilihat dari kecocokan hasil fitting atas model terhadap data asli. Hasil kecocokan ini dapat dilihat melalui tabel klasifikasi. Tabel klasifikasi tersebut dapat dilihat pada Tabel 4. di bawah ini

Tabel 4. Hasil Estimasi Model Logit

\begin{tabular}{|c|c|c|c|c|c|c|}
\hline & \multicolumn{3}{|c|}{ Estimated Equation } & \multicolumn{3}{|c|}{ Constant Probability } \\
\hline & Dep $=0$ & $\mathrm{Dep}=1$ & Total & $\mathrm{Dep}=0$ & Dep $=1$ & Total \\
\hline$P(D e p=1)<=C$ & 56 & 11 & 67 & 56 & 11 & 67 \\
\hline$P(D e p=1)>C$ & 0 & 0 & 0 & 0 & 0 & 0 \\
\hline Total & 56 & 11 & 67 & 56 & 11 & 67 \\
\hline Correct & 56 & 0 & 56 & 56 & 0 & 56 \\
\hline$\%$ Correct & 100.00 & 0.00 & 83.58 & 100.00 & 0.00 & 83.58 \\
\hline$\%$ Incorrect & 0.00 & 100.00 & 16.42 & 0.00 & 100.00 & 16.42 \\
\hline Total Gain* & 0.00 & 0.00 & 0.00 & & & \\
\hline \multirow[t]{3}{*}{ Percent Gain** } & NA & 0.00 & 0.00 & & & \\
\hline & \multicolumn{3}{|c|}{ Estimated Equation } & \multicolumn{3}{|c|}{ Constant Probability } \\
\hline & Dep $=0$ & Dep $=1$ & Total & $\mathrm{Dep}=0$ & Dep $=1$ & Total \\
\hline$E(\#$ of $D \in$ & 48.05 & 7.95 & 56.00 & 46.81 & 9.19 & 56.00 \\
\hline$E(\#$ of $D e p=1)$ & 7.95 & 3.05 & 11.00 & 9.19 & 1.81 & 11.00 \\
\hline Total & 56.00 & 11.00 & 67.00 & 56.00 & 11.00 & 67.00 \\
\hline Correct & 48.05 & 3.05 & 51.10 & 46.81 & 1.81 & 48.61 \\
\hline$\%$ Correct & 85.80 & 27.72 & 76.26 & 83.58 & 16.42 & 72.56 \\
\hline$\%$ Incorrect & 14.20 & 72.28 & 23.74 & 16.42 & 83.58 & 27.44 \\
\hline Total Gain* & 2.22 & 11.30 & 3.71 & & & \\
\hline Percent Gain ${ }^{\star \star}$ & 13.52 & 13.52 & 13.52 & & & \\
\hline
\end{tabular}

${ }^{*}$ Change in "\% Correct" from default (constant probability) specification

**Percent of incorrect (default) prediction corrected by equation

Tabel 4. di atas, menjelaskan bahwa pada bagian atas- kiri untuk kolom estimated equation, digunakan klasifikasi model logit pada persamaan (4), diperoleh dari 67 data pada kenyataannya bernilai 0 , dan jika diestimasi menggunakan persamaan (4) dengan menggunakan ambang batas 0,5 diperoleh 56 diantaranya dikategorikan bernilai 0 dan 11 data bernilai 1. Kemudian didapatkan persentasi identifikasi yang benar adalah sebesar $83,58 \%$.

Selanjutnya untuk melihat apakah model logit diatas merupakan model yang tepat dan terbaik dari data yang ada, maka perlu dilakukan pengujian model. Pengujian model ini dilakukan menggunakan uji Goodness of fit-test Hosmer-Lemeshow. Menurut (Hendayana, 2012), pada Goodness of fit-test Hosmer-Lemeshow, jika nilai p-value lebih besar dari tingkat signifikansi, maka model logit layak untuk digunakan. Berdasarkan analisis menggunakan software EViews 9, diperoleh nilai p-value pada penelitian ini sebesar 0,2471. Dan nilai $p$-value ini lebih besar dari tingkat signifikansi (5\%). Artinya model logit yang terbentuk layak untuk digunakan. Oleh karena itu, persamaan (4), merupakan model logit yang layak digunakan.

Persamaan (3), diinterpretasikan sebagai perbandingan peluang mahasiswa untuk mendapatkan nilai A terhadap peluang tidak mendapatkan nilai A. Kemudian variabel model pembelajaran ternyata juga mempengaruhi, terhadap nilai akhir dari mahasiswa untuk mendapatkan peluang nilai A atau tidak.Dan berdasarkan persamaan (3) juga diperoleh nilai odd ratio. Nilai odd ratio, menurut (Tampil, Komalig, \& Langi, 2017) adalah merupakan sekumpulan peluang, yang dibagi oleh peluang lainnya. Bilai nilai odd ratio 
sama dengan 1 artinya kedua variabel tidak ada hubungan, bila kurang dari satu, maka kedua variabel terdapat hubungan negatif terhadap perubahan kategori dari nilai $x$, dan demikian juga sebaliknya. Nilai odd ratio dapat dicari dengan menggunakan persamaan (5) dibawah ini

$$
\frac{\pi_{i}}{1-\pi_{i}}=e^{\beta_{0}+\beta_{1} x_{1}+\cdots+\beta_{p} x_{p}}
$$

Dengan menggunakan persamaan (5), diatas dapat diperoleh nilai odd ratio, dari penelitian ini adalah sebagai berikut

$$
\frac{\pi_{i}}{1-\pi_{i}}=e^{-2.420368+1.968383 x_{2}}
$$

Berdasarkan persamaan (6) diatas, jika model pembelajaran yang digunakan menggunakan model pembelajaran group resume yang bernilai 1, maka akan meningkatkan nilai odd ratio untuk mendapatkan nilai A sebesar $\exp (1,968383)$ kali atau sebesar 7,159090874 kali, dibandingkan jika menggunakan model pembelajaran selain group resume yang bernilai 0 , maka tidak akan meningkatkan nilai odd ratio untuk mendapatkan nilai A. Dengan demikian dapat dikatakan bahwa adanya efek atau adanya pengaruh penggunaan model pembelajaran yang berbeda terhadap nilai akhir mahasiswa.

\section{Kesimpulan}

Berdasarkan pembahasan diatas, dapat disimpulkan bahwa model persamaan logistik dan model logit yang tepat yang dapt mewakili data adalah $P(Y=j \mid x)=\pi(x)=\frac{e^{-2.420368+1.968383 x_{2}}}{1+e^{-2.420368+1.968383 x_{2}}}$ dan $g(x)=-2.420368+1.968383 x_{2}$, dengan nilai odd ratio $\frac{\pi_{i}}{1-\pi_{i}}=e^{-2.420368+1.968383 x_{2}}$. Hal ini menunjukkan bahwa jika menggunakan model pembelajaran group resume, maka akan meningkatkan nilai odd ratio untuk mendapatkan nilai A sebesar 7,159090874 kali. Dan dengan kata lain, adanya pengaruh penggunaan model pembelajaran yang berbeda terhadap nilai akhir mahasiswa.

\section{Ucapan Terimakasih}

Ucapan terima kasih penulis sampaikan kepada Universitas Amikom Purwokerto, yang sudah mendanai penelitian ini.

\section{Daftar Pustaka}

Anas, MUh dan Murti, W. (2017). PENGARUH PEMBELAJARAN KOOPERATIF TIPE GR (GROUP RESUME) TERHADAP AKTIVITAS DAN HASIL BELAJAR BIOLOGI KELAS VIII SMP ISLAM DARUL HIKMAH MAKASSAR. Jurnal Ilmiah Pena: Sains Dan Ilmu Pendidikan, 10 No 1, 1-8.

Darnah. (2011). Regresi Logistik Ordinal untuk Menganalisis Faktor-Faktor yang Mempengaruhi Perilaku Sexual Remaja. Jurnal Eksponensial, 2.

Hendayana, R. (2012). ADOPSI TEKNOLOGI PERTANIAN Application Method of 
Logistic Regression Analyze the Agricultural Technology Adoption. (2), 1-9.

Isjoni, H. (2009). Pembelajaran kooperatif. Yogyakarta: Pustaka Pelajar.

Muinah Kusnul Kotimah, S. P. W. (2014). Model Regresi Logistik Biner Stratifikasi Pada

Partisipasi Ekonomi Perempuan Di Provinsi Jawa Timur. Jurnal Sains Dan Seni Pomits, 3(1).

Mutakin, T. Z. (2013). Analisis Kesulitan Belajar Kalkulus 1 Mahasiswa Teknik Informatika. 3(1), 49-60.

Rosadi, D. (2011). Analisis Ekonometrika \& Runtun Waktu Terapan dengan R. Yogyakarta: ANDI OFFSET.

Rosadi, D. (2012). Ekonometrika dan analisis runtun waktu terapan dengan eviews. Yogyakarta: ANDI OFFSET.

Dewi, S. R, dkk. (2018). Klasifikasi Pemilihan Program Studi di Fakultas MIPA Universitas Lambung Mangkurat Menggunakan Regresi Logistik Multinomial. Jurnal Matematika Murni Dan Terapan “Epsilon,”12(2), 19-29.

Sutiman, Antuni Wiyarsi, E. P. (2014). Efektifitas Pembelajaran Kooperatif dalam Meningkatkan Aktivitas dan Motivasi Belajar Mahasiswa pada Perkuliahan Filsafat Ilmua. Jurnal Pendidikan Matematika Dan Sains, 1, 51-64.

Tampil, Y. A., Komalig, H., \& Langi, Y. (2017). Analisis Regresi Logistik Untuk Menentukan Faktor-Faktor Yang Mempengaruhi Indeks Prestasi Kumulatif ( IPK ) Mahasiswa FMIPA Universitas Sam Ratulangi Manado Logistic Regression Analysis To Determine Factors Affecting The Grade Point Average ( GPA ) Of FM. JdC, 6 No (2).

Wahyuni, A. (2017). Analisis Hambatan Belajar Mahasiswa Pada Mata Kuliah Kalkulus Dasar. 1(1), 10-23. 